\title{
GCU
}

Glasgow Caledonian

University

University for the Common Good

\section{Creating sustainable cities one building at a time: towards an integrated urban design framework}

Futcher, Julie; Mills, Gerald; Emmanuel, Rohinton; Korolija, Ivan

Published in:

Cities

DOI:

10.1016/j.cities.2017.03.009

Publication date:

2017

Document Version

Author accepted manuscript

Link to publication in ResearchOnline

Citation for published version (Harvard):

Futcher, J, Mills, G, Emmanuel, R \& Korolija, I 2017, 'Creating sustainable cities one building at a time: towards an integrated urban design framework', Cities, vol. 66, pp. 63-71. https://doi.org/10.1016/j.cities.2017.03.009

\section{General rights}

Copyright and moral rights for the publications made accessible in the public portal are retained by the authors and/or other copyright owners and it is a condition of accessing publications that users recognise and abide by the legal requirements associated with these rights.

Take down policy

If you believe that this document breaches copyright please view our takedown policy at https://edshare.gcu.ac.uk/id/eprint/5179 for details of how to contact us. 


\section{Creating sustainable cities one building at a time: Towards an integrated urban design framework}

Julie Futcher ${ }^{1^{*}}$, Gerald Mills ${ }^{2}$, Rohinton Emmanuel ${ }^{3}$, Ivan Korolija ${ }^{4}$,

${ }^{1}$ Urban Generation, email: julie@climate22.com

${ }^{2}$ University College Dublin, email: gerald.mills@ucd.ie

${ }^{3}$ Glasgow Caledonian University, email: Rohinton.Emmanuel@gcu.ac.uk

${ }^{4}$ University College London, email: ivan.korolija@gmail.com

\section{Please cite as:}

Futcher J, Mills G, Emmanuel R, Korolija I, 2017. Creating sustainable cities one building at a time: Towards an integrated urban design framework, Cities, DOI:

http://dx.doi.org/10.1016/j.cities.2017.03.009 


\title{
Creating sustainable cities one building at a time: Towards an integrated urban design framework
}

\begin{abstract}
One of the tenets of urban sustainability is that more compact urban forms that are more densely occupied are more efficient in their overall use of space and of energy. In many designs this has been translates into high-rise buildings with a focus on energy management at their outer envelopes. However, pursuing this building focused approach alone means that buildings are treated as standalone entities with minimal consideration to their impact on the surrounding urban landscape and vice versa. Where urban density is high, individual buildings interact with each other, reducing access to sunshine and daylight, obstructing airflow and raising outdoor air temperature. If/when each building pursues its own sustainability agenda without regard to its urban context, the result will diminish the natural energy resources available to nearby buildings and worsen the outdoor environment generally. This paper examines some of these urban impacts using examples from the City of London where rapid transformation is taking place as very tall buildings with exceptional energy credentials are being inserted into a low-rise city without a plan for the overall impact of urban form. The focus of the paper is on access to sunshine and wind and the wider implications of sustainable strategies that that focuses on individual buildings to the exclusion of the surrounding urban landscape. The work highlights the need for a framework that accounts for the synergistic outcomes that result from the mutual interactions of buildings in urban spaces.
\end{abstract}

KEY WORDS - building energy management; urban climate effects; building and urban form

\section{Introduction}

Greenhouse Gas (GHG) emissions from energy use are typically dominated by three sectors: buildings, transport and industry. One of the ubiquitous urban policies for building energy demand reduction is compact cities with increased building densities (Breheny, 1992; Jabareen, 2006) and at the same time: making individual buildings more efficient in their energy use whilst creating pleasant and accessible outdoor spaces. Building energy management is central to the discussion on sustainable cities. In 2010 , buildings accounted for $32 \%$ of total global final energy use and $19 \%$ of energy-related GHG emissions. For economies included in the Major Economies Forum (including the EU, US and other OECD countries) where per capita energy use is already high, the contribution of buildings is about $40 \%$ of total demand (IEA, 2014; Porse et al., 2016). At a city scale in these economies, buildings and transport are typically responsible for up to $80 \%$ of energy use and a similar proportion of GHG emissions (IEA, 2010). Given the increased demand for floor area fuelled by global urban population growth, building related energy demand is likely to increase further everywhere.

Current building energy management (BEM) strategies treat each building as independent or standalone entity in which emphasis is placed on the material fabric of the building and the efficiency of internal systems. This approach has been termed 'generic', as it is not specific to the geographical, climatic or site conditions where a building is located (Blakely 2007; Mourshed, 2016). In urban settings, this means that interdependent and dynamic energy relationships (that includes shading and sheltering) that occur between buildings are not considered and the combined impact of building groups on the adjacent outdoor space and its use are not considered adequately (Figure 1). The emphasis on a generic approach to BEM has been justified on the basis that the thermal 
elements are inherently efficient before considering the impact of other technologies, including renewables. However, despite buildings being designed as if independent stand-alone entities will perform differently in a changing urban setting; moreover, they will interact with other buildings and the outdoors to modify their micro-climatic environment, often for the worse. These effects can be accentuated when buildings with a radically different built form are inserted into an existing urban landscape causing a redistribution of natural resources. Unfortunately, the effect of building form on the urban environment is limited in current assessment methodologies and potential benefits and costs that accrue to the public realm from individual buildings are largely ignored (Erell and Williamson, 2006).

\section{FIGURE -1 EXAMPLES OF TALL BUILDINGS}

In this paper, we explore some of the consequences of the current stand-alone BEM strategy using case study developments from the City of London, which is undergoing significant change as tall and very tall buildings are inserted into a low-rise and historic urban landscape. The buildings under consideration here have either an office or residential function, which have distinct patterns of energy usage and energy management strategies. Figure 2 presents a graphical generalisation of typical load profiles for 'residential' and 'commercial (office)' buildings. The load profile for typical 'residential' buildings is based on the methodology proposed by Yao and Steemers (2005), which shows twin peaks - a smaller, early morning peak and a larger and more sustained evening peak . For offices, which are occupied during the daytime and working week, the method follows the protocols specified by the U.S. Department of Energy for its EnergyPlus software (US DOE, n.d.). The load profile is one of a single, mid-day peak that coincides with the occupied hours of the building. Thus, BEM relies on regulating the internal energy gain associated with the metabolic heat generated by the occupants and the waste heat generated by lighting and electronic equipment. In circumstances where there is a daytime cooling demand (as is common in well insulated buildings) the external energy gain through the fabric, especially via glazed surfaces, is undesirable. By comparison, residential buildings have offset energy demands that peak in the morning and evening and over weekends. These buildings have a 'cross-over' point in the morning and evening, corresponding with the peak commuting times. For these buildings, the daytime external energy gain is desirable as it can limit heating demand in the evening hours. These descriptions are highly generalised but that are appropriate for the densely occupied and built city centre context presented here.

\section{FIGURE - 2 ENERGY PROFILE}

\section{Buildings and the urban climate effect}

The influence of 'built form' on the local climate is well known and alters nearly every aspect of natural energy, hydrological, and circulation systems (Oke, 1987). These effects are the outcome of aspects of both urban form and function. Form describes the characteristics of the urban surface: the geometry created by buildings and streets (Oke, 1987). Function describes the activities associated with human occupation that requires a constant flux of energy and materials to be sustained (Oke, 1987). Whereas, urban form has the effect of redistributing the natural resources available at a place (such as channelling wind or shading pavement), urban function adds waste heat, water and materials to the environment. Together, these attributes create an immense variety of micro-climates at ground level based on shade and sunlight, areas of shelter and gustiness, poor and good air quality and so on. Perhaps the best known of the urban climate impacts is the urban heat island (UHI), which is a ubiquitous feature of cities and refers to the warmer air and surface temperature found in cities. A UHI map for London (Wolf and McGregor, 2013) shows a pattern that is typical of many mid-latitude western cities: its magnitude increases from the edge of the city 
(residential, low built density and significant green space) toward the city centre (commercial, high built density and little green space) (Oikonomou, et al., 2012).

The effects of urban form on local climate, thermal comfort and energy consumption have been well researched during the past fifty years. Starting with Olgyay's (1963) work on bio-regionalism, research in related areas have led to guidelines for climate sensitive urban design (Givoni, 1988); form optimisation for different climatic contexts - solar access rights in temperate climates (Knowles, 1981), solar shading in the tropics (Emmanuel, 1993), passive urban form for tropical cities (Martins et al., 2014), archetypical built forms for arid climates (Ratti et al., 2003); passive energy resource enhancement (Steemers et al., 2000) and urban energy management (Ratti et al., 2005; Futcher et al., 2013). Tools for the analysis of energy performance of urban form - such the LT method (Baker and Steemers, 1994), Energy Index (Yannas, 1994) or Urban Energy Index for Buildings (UEIB, Rodríguez-Álvarez, 2016) have been proposed. Much of this work has focussed on the solar resource but there has been work on the potential for both harvesting wind in cities (e.g. Sunderland et al., 2013) and ensuring ventilation at street level ( $\mathrm{Ng}, 2009)$. This research emphasises the need for energy management at a building group scale to complement sustainability initiatives at a building scale.

In London, Kolokotroni et al. (2012) examined the impact of current and projected UHI for a typical office building and found that the heating (cooling) demand decreases (increases) toward the city centre where the UHI is strongest. They argue for improved weather files that account for both the $\mathrm{UHI}$ and projected climate change that could be used to ensure building energy efficiency for the future. Further studies found that identical buildings perform differently as a result of even small changes in their surrounding urban setting and that building location within the UHI can be optimised to correspond with energy demands associated with occupation and activity patterns (Futcher et al 2013).

These issues are recognised in The London Plan (GLA, 2016), specifically in its policy on Overheating and Cooling, which states that: Major development proposals should reduce potential overheating and reliance on air conditioning systems and demonstrate this in accordance with the following cooling hierarchy: minimise internal heat generation through energy efficient design; reduce the amount of heat entering a building in summer through orientation, shading, albedo, fenestration, insulation and green roofs and walls; manage the heat within the building through exposed internal thermal mass and high ceilings; passive ventilation; mechanical ventilation and; active cooling systems (ensuring they are the lowest carbon options). Note the priority given to the utilisation of natural resources, which are often greatly diminished in cities.

In parallel to these, work on 'sustainable urban form' has progressed in recent years to include the notion of urban resilience (ability to adapt to environmental stress without contributing to further acceleration of that stress) in the face of local and global climate change. Several authors have proposed urban parameters that are said to contribute to urban sustainability (e.g. compactness densely built and occupied places, mixed landuse - Breheny, 1992; compactness, sustainable transport, density, mixed land uses, passive solar design, and greening - Jabareen, 2006) while other contend that no universal relationships exist on the most desirable urban form in the context of sustainability (e.g. Frey, 1999; Williams et al., 2000). Nevertheless, and even accounting for the wide variations in the definition of 'urban form' (from two dimensional land-use patterns - Anderson, 1996 to three dimensional attributes such as size, density, clustering, evenness in size, edge density, and compactness - Schwarz, 2010) there appears to be a consensus towards 'compact' urban form as key to urban sustainability (e.g. Stone and Rogers; 2001, Yin et al., 2013).

Yet, the unintended energy, thermal comfort, air quality and ventilation interactions and consequences of compact urban form is only beginning to be appreciated. While at local scales, 
strong correlations exist between exposed surface area and energy use, at district scale, a sharp increase in electricity use is seen in districts where buildings are deeper (in which, for example, airconditioning and permanent artificial lighting are typically required) (Steadman et al., 2014). Although compact cities may decrease the operational domestic heating energy consumption per household (Liu and Sweeney, 2012), they tend to have poor air quality; higher concentrations of $\mathrm{NO}_{2}$ and $\mathrm{PM}_{10}$ and densely populated cities suffer from higher $\mathrm{SO}_{2}$ concentration (Rodríguez et al., 2016) - with a potential increase in the use of energy for air conditioning. Furthermore, compact cities with low surface-to-volume ratios minimize the building energy consumption for space heating/cooling, but maximize the outdoor heat stress (Martilli, 2014).

Taken as a whole, achieving sustainability at an urban scale requires an integrated approach that accounts for the interactions between buildings that modify the distribution of natural resources and their impact on the outdoor environment. However, this perspective is not generally considered in policies. For example, in the London Plan (GLA, 2016) new developments will be expected to reduce carbon dioxide in accordance with a hierarchy: first, reduce energy demand by adopting sustainable design principles; second, source energy efficiently, by prioritising decentralised energy and; third, use renewable energy. However, the wider urban impact of the development is generally limited to a minimal microclimate assessments that includes daylight/sunlight/shadowing (permanent and transient), light pollution (glare/solar glare, sky glow, light trespass, light ingress) and under certain conditions, wind assessments. In this paper we examine the unintended (but predictable) consequences of policies that prioritise a generic stand-alone approach that does not account for a buildings net-energy beyond its envelope.

\section{London's changing skyline}

London's landscape is changing rapidly as very tall buildings are being built or planned. As of March 2016, there were 436 planning applications for buildings of 20 storeys or more in Greater London, which covers an area of $1,572 \mathrm{~km}^{2}$ and is divided into 32 boroughs (Figure 3 ). At the time of writing 89 buildings are under construction, 233 approved and 114 yet to receive planning permission; $70 \%$ are residential with an element of retail, community or leisure and represents a huge increase on the current level of buildings of 20 storeys or more. Nearly $20 \%$ of these tall buildings are planned for the City of London, which encompasses just $2.9 \mathrm{~km}^{2}$ and contains London's historic core and financial district. Relatively few reside in the City (just 7,500 in 2011) but it is a major centre of employment. Over 450,000 are employed, which represents $9 \%$ of Greater London's employment, and $1.5 \%$ of the UK's total employment. Not surprisingly the demand for space is at a premium, land values are high and there is a need to maximise floor-space (City of London 2011); as of $31^{\text {st }}$ March 2015 there was $8,739,000 \mathrm{~m}^{2}$ of office floor-space, much of it concentrated in an area known as the Eastern Cluster which has been designated as a key area for delivery of tall Buildings to provide growth and modernisation of office stock (City of London Corporation 2015). More generally however, the stated policy in the City is to allow 'tall buildings of world class architecture and sustainable design in suitable locations and to ensure that they take full account of the character of their surroundings, enhance the skyline and provide a high quality public realm at ground level' (City of London 2011). The policy implies that 'sustainability' of densification by tall buildings is to be achieved by exploiting resources available at site. The policy thus exemplifies the 'stand-alone' nature of the current approach.

\section{FIGURE 3 LOCATION AND NUMBER OF TALL BUILDINGS}

The latter is evaluated mainly through compulsory daylight/sunlight and overshadowing impact assessments but there is no overarching plan that considers the aggregate impact of these tall buildings. The main constraints on the emerging skyline is the requirement to retain historic views 
and ensure air space safety (Tavernor and Gassner 2010; Marrs 2016). For example, the façades of both 122 Leadenhall (The Cheesegrater) and 52-54 Lime Street (The Scalpel - currently under construction) slope with height to give the buildings a tapered appearance and protect views of St Paul's cathedral; both buildings lose valuable floor space at the upper floors (Figure $\mathbf{4}$ buildings 07 \& 08 respectively). However, protecting these views was never intended to affect the status of London as a premier world city (Tavernor and Gassner 2010).

\section{FIGURE 4: CITY PROFILE - SECTION SHOWING THE EASTERN CLUSTER}

In addition to planning regulations, rights-to-light easements exert some influence. An easement is a benefit that relies on access over a property owned by another and exists (or may be created) when a property has enjoyed uninterrupted access for a period of time, usually 20 years. These rights exist even if the original building has been replaced, and carry significant weight. In this context, the rightto-light cannot be significantly diminished without the consent of the owner; its value has been confirmed by the Heaney Case (England and Wales High Court (Chancery Division) Decisions 2010) where the court found in favour of a claimant against a developer of an adjacent property - the net effect was a judgment to modify the height of the offending development to restore that right.

The impact of a proposed building on both the daylight and sunlight of the existing area, including the surrounding buildings, public spaces, gardens etc., are estimated at the planning stage through an outcome based approach. For larger schemes, developers are required to undertake an Environmental Impact Assessment that evaluates impacts on wind, daylight, biodiversity, views etc. However, there is no statutory provision that stipulates the form/standard of an Environmental Statement itself. Nevertheless, it should include a full description of the project, its positive and negative environmental impacts and how significant adverse effects on the environment will be prevented, reduced, remedied and, where necessary offset. Even when developments follow these rules diligently, unintended and undesirable outcomes can take place. Moreover, many of these outcomes are readily observable to the pedestrian.

\subsection{Energy shedding}

Anthropogenic energy describes the heat flux that is sourced from humans and their activities and exhausted to the outdoor environment as a normal part of building operations. One of the bestknown impacts of commercial buildings in London is the solar glazing effect where sunlight is reflected off extensive glass envelopes onto other buildings and streets. In many instances, the solar glare is a transient effect that has no significant effect however, the design of the building can focus the reflected energy. Perhaps the best known of these is a tall building at 20 Fenchurch Street (20FC AKA The Walkie Talkie Building 11 - Figure 4), which was designed by Rafael Viñoly. Also known as the 'Walkie Talkie' because of its unusual shape (Figure 5) that was driven by the desire to increase floor space (and rent per sq. $\mathrm{m}$ ) towards the roof. The result is a building with a distended form as the bulk of the floor space is positioned above the surrounding rooftops. To enclose the building, the envelope is curved into a concave shape on its south-facing façade. 20FC provides over $60,000 \mathrm{~m}^{2}$ of much needed office space and was awarded a BREEAM 2011 Excellent rating. It also gave over the valuable top three floors as a public use 'Sky Garden' with dramatic views over the River Thames and the City of London. The building's energy management strategy, its economic merit, and the 'Sky Garden', qualified the building to be of sufficient economic, social and environmental value for the City of London Corporation (the municipal government for the City of London) to invoke the Section 237 of the Town and Country Planning Act 1990, which allows a local authority to acquire land to override easements and other rights of third parties for planning purposes.

FIGURE 5. 20 FENCHURCH STREET (20FC) 
Notwithstanding architectural criticisms of its form, 20FC represented precisely what the tall building guidelines intended. However, its curved southern façade has created undesirable microclimates in the nearby streets that only became apparent once the building was near completion (early September 2013). First, the curvature of the glass facade focused and concentrated the early afternoon solar beam onto an adjacent street raising the surface temperatures above $100^{\circ} \mathrm{C}$ and melting parts of a parked car. To address this nuisance an expensive retrofit was undertaken that added shading devices to block the deflected beam. Second, the building form also redirects the faster-moving, high-level winds off the River Thames to the foot of the tower, affecting pedestrian comfort levels. These effects are difficult to resolve post construction. Critically, neither of these outcomes were identified in the pre-construction assessments, unlike the areas affected by right-tolight. As result, the City of London Corporation now requires independent verification of wind studies to be undertaken, alongside recognising the need for clearer guidelines.

There are other buildings in the City that exhibit these effects, including the nearby Fosters + Partners Willis building $(125 \mathrm{~m})$ that reflects the afternoon Sun onto the roof of the adjacent Lloyds building (figure 1). In building assessments, this 'displaced' energy is not attributed to the reflecting building and is not included as additional external energy gain to the recipient building. Elsewhere, the Eastern Cluster, which is formed as a group of tall, tightly-packed buildings, is a notoriously windy spot, where the combination of downdrafts and the acceleration of winds through narrow gaps between buildings (the Venturi effect) creates strong eddies at ground level that affect outdoor use.

\subsection{Energy harvesting}

Much sustainable literature focusses on the use of natural resources (mostly sun and wind) to reduce the reliance on fossil-fuel derived energy either through power generation or passive design. However, these resources are limited over any given area and if one building 'harvests' these it is often at the expense of others. This effect is especially the case for poorly oriented tall and wide buildings that are significantly higher than the surrounding neighbourhood. To illustrate these impacts we have chosen two developments, one built and the other in its planning phase. They are distinguished by their functions, which regulates their occupation patterns and energy gains and losses.

Tall commercial Buildings: The design of the $230 \mathrm{~m}$ tall building at 110 Bishopsgate (110BG AKA the Heron Tower - building 02 Figure 4) was partly determined by site restrictions and those related to its visual impact. In this instance, each façade is expressed differently in terms of finish and height (Tavernor and Gassner 2010). A distinguishing feature of 110BG, which was completed in 2011, is the south-facing façade which has $3,200 \mathrm{~m}^{2}$ of embedded photovoltaic (PV) cells that cover much of the face and acts as a solar shield. To accommodate the PV array much of the space behind the southern façade is unavailable as office space and the energy infrastructure is arranged vertically, rather than horizontally. This array supplies an estimated $92,000 \mathrm{kWh} / \mathrm{yr}$ or about $2.2 \%$ (approximately) of the buildings annual energy needs and forms part of its sustainability strategy (the building achieved an excellent BREEAM rating).

However, this strategy is reliant on access to the Sun over the southern horizon, which is not protected under planning or civil law frameworks. Directly south of the $110 B G$, just $30 \mathrm{~m}$ from its PV façade, is a new high-rise development is being constructed that will be $172 \mathrm{~m}$ tower tall when complete. Both its height and width will shade the PV array and reduce its electricity generation by an estimated 40\% (Futcher et al., 2014). 100 Bishopsgate (100BG Building 03 figure 04) now finds itself in the same situation as the buildings that it shades, deprived of a potential source of energy (Figure 6). In urban terms, the energy strategy of one building has been trumped by the design of another without redress. Ironically, in a conventional tall building with a glazed façade the shading provided by its neighbour is a benefit, reducing external energy gain; moreover, the valuable floor 
space which has been set aside to incorporate the solar generated electricity, would be available. In fact, using Energy Plus, a dynamic simulation modelling tool, the shading effect could lower cooling demand to these offices by $30 \%$. In other words, the shading impact of the new development could have provided a benefit for $110 \mathrm{BG}$ by reducing the external energy gain, rather than a cost by depriving it of both solar power and usable office space (Appendix 1). The interdependent energy relationship between these two buildings clearly demonstrates that the buildings energy management extends beyond the buildings physical envelope and that by overlooking these interdependent effects we are missing opportunities to improve building energy management at a larger scale than the individual building.

\section{FIGURE 6. HERON TOWER (100BG)}

Tall residential buildings: For residential buildings in London access to the solar beam is nearly always beneficial and an unobstructed (well-insulated) glazed south-facing façade is a passive heating feature that can be used to offset the need for night-time heating (Figure 7). Tall buildings in residential neighbourhoods can have significant impacts both on the energy demands of neighbouring buildings and the use of outdoor space. To illustrate this, we selected the proposed Bishopsgate Goodsyard (BGY) development a 4.4 hectare brownfield site (Bishopsgate Goodsyard), which falls within the boundary of two London boroughs, Hackney and Tower Hamlets and is located at the northern edge of the City of London. The plans for BGY have proved very controversial, principally owing to the massing and height of a set of towers that are arranged east-to-west on an elevated plinth. The Greater London Authority's recommended the mayor reject the latest application in April 2016 on grounds that included overshadowing of nearby neighbourhoods. It is worth examining the projected impact of the planned project as it is likely to foretell disputes over London's emerging tall building landscape. The full set of submitted planning documents can be found at the Tower Hamlets website ${ }^{1}$.

\section{FIGURE 7. BISHOPS GOODS YARD (BGY)}

Whilst currently in abeyance The BGY site was to be developed for mixed use and included up to 1,356 residential units, nearly $65,859 \mathrm{~m}^{2}$ of office and $17,500 \mathrm{~m}^{2}$ of retail floor area. This space was to be contained in 12 buildings ranging in height from $177.6 \mathrm{~m}$ to $23.6 \mathrm{~m}$. The design of the development was due partly to site restrictions that specified about $30 \%$ of the site should be set aside for public space, including parkland. The design of BGY was anticipated to reduce $\mathrm{CO}_{2}$ emissions of up to $27 \%$ beyond the Part L 2013 baseline, which governs conservation of fuel and power in buildings; this was to be achieved using passive design and energy efficiency measures, combined heat and power plants and roof-level PV systems. The passive design contribution is based on access natural ventilation and sun for light and warmth in winter (Hoare Lea 2014). As part of the environmental impact assessment both the wind and solar impacts of BGY were assessed. The former employed wind tunnel methods to examine the impact of the development on the use of outdoor space and concluded that there would be minor adverse effects that which could be managed through design interventions.

On the other hand, daylight and sunlight were found to be adversely affected by the BGY: The majority of residential properties assessed for daylight and sunlight were found to experience negligible to minor adverse impacts, however there were a number of properties that would experience impacts of moderate to major significance. Additionally, there were a number of external amenity areas which would experience a reduction of sun hours on ground that would give rise to

\footnotetext{
${ }^{1}$ https://development.towerhamlets.gov.uk/online-applications/
} 
moderate and major impacts, and a number of properties which would experience overshadowing leading to a minor adverse impact during summer and moderate to major during winter (Environmental Statement: Non-technical summary). However, the developers argued that the current level of access was an 'unrealistic baseline' as the BGY site had been vacant for so long and that the environmental benefits of the proposed development outweighed the costs.

Environmental assessment reports do not currently evaluate the energy impacts of large developments, although they can be significant, especially in areas that already experience fuel poverty. One of the neighbourhoods affected by BGY is the Boundary Estate (BE), which is a historic housing development dating from the $19^{\text {th }}$ Century. Ironically, its layout (wide streets radiating from a central public park) was based on public health theories that emphasised solar access and ventilation. In the intervening years it has not been extensively retrofitted so that the fabric is poorly insulated by modern standards. Futcher et al. (2015) used Energy Plus to estimate current heating demand at $88.68 \mathrm{kWh} / \mathrm{m}^{2}$ between September to March. The impact of the proposed BGY would be to increase these loads by up to $5 \%$, with the largest increases occurring where surfaces currently enjoy the highest levels of solar gains i.e., the upper floors closest to BGY. If the fabric of the Boundary Estate were upgraded to Part L 2014, the winter heating demand is lower $\left(24.75 \mathrm{kWh} / \mathrm{m}^{2}\right)$ but the relative impact of over shadowing is even greater $(9 \%)$. In this case, the modern 'sustainable' energy strategy for the BGY cannot be decoupled from a wider urban energy strategy.

\section{Conclusions}

These case studies illustrate the limits to current building-scale energy sustainability assessments in urban settings where mutual interactions influence the ambient conditions and external energy gains of all buildings. These effects are greatest where buildings are closely spaced and are particularly strong where tall buildings are inserted into a low-lying urban setting. In the latter case, the relationships are asymmetric, and the taller building has a far greater impact on lower buildings than vice versa. The significance of the impact depends on the function of the building, which regulates its energy demand, and how it manages external energy gains (shed or harvest). Each case study outlined here demonstrates the need for a neighbourhood-scale assessment to building energy sustainability. Current building energy management strategies end the building envelope and climatic aspects of environmental impact assessments are limited to access to daylight, sunlight and pedestrian winds. There is no right to natural resources and to share these equitably in a built environment would require a comprehensive urban design that includes building form and fabric, layout and street width and orientation. However, in a city like London that is already built, many of these decisions have already been made and urban landscape is being changed relatively slowly, one building at a time. Where the development radically changes the existing landscape (Figure $\mathbf{3}$ ), buildings that are designed to be energy efficient may make the neighbourhood less so. The current fabric-first approach that treats the building as an isolated entity needs to be re-evaluated to include these impacts. Otherwise, the energy efficiency of the emerging urban form may be less than the sum of its parts.

\section{Acknowledgements}

The lead author would like to acknowledge financial support provided by the Glasgow Caledonian University via 'The Role of Building and Urban Form as an Energy Management Parameter Project,' to aid the present work. 


\section{References}

Anderson W. 1996. Urban form, energy and the environment: A review of issues, evidence and policy. Urban Studies, 33, pp. 7-36

Baker NV, Steemers KA. 1994. LT Method version 2.0. Cambridge, UK: Cambridge Architectural Research Ltd

Blakely E. 2007. Urban Planning for Climate Change Lincoln Institute of Land Policy, Working Paper

Breheny M, (ed.). 1992. Sustainable Development and Urban Form. London: Pion

City of London 2011. Local Development Framework - Core Strategy - Development Plan Document delivering a World Class City. http://www.cityoflondon.gov.uk/services/environment-andplanning/planning/planning-policy/local-development-

framework/Documents/The\%20Core\%20Strategy\%20September\%202011.pdf

City of London Corporation 2015 Offices in the City of London 2015 Update - Department of the Built Environment

Emmanuel R. 1993. A hypothetical 'shadow umbrella' for thermal comfort enhancement in the Equatorial Tropical urban outdoors, Architectural Science Review, 36, pp. 173-184

England and Wales High Court (Chancery Division) Decisions 2010 HKRUK II (CHC) vs. Heaney, available at: http://www.bailii.org/ew/cases/EWHC/Ch/2010/2245.html Ch/2010/2245.html

Erell E, Williamson T. 2006. Simulating air temperature in an urban street canyon in all weather conditions using measured data from a reference meteorological station, International Journal of Climatology, 26, pp. 1671-1694

Frey H. 1999. Designing the City: Towards a More Sustainable Urban Form. London: E \& FN Spon

Futcher J, Kershaw T, Mills G. 2013. Urban form and function as building performance parameters, Building and Environment, 62, pp. 112-123

Futcher J, Mills G, Korolija I, Zhang Y. 2014 Shadowlands, CIBSE Journal http://portfolio.cpl.co.uk/CIBSE/201407/modelling-tall-buildings/

Futcher J, Mills G, Korolija I. 2015 Good Neighbours RICS Journal https://issuu.com/ricsmodus/docs/building control journal june july

Givoni B, 1998. Climate Considerations in Building and Urban Design, New York: Wiley

Greater London Authority (2016) The London Plan: The spatial development strategy for London. Available at: https://www.london.gov.uk/what-we-do/planning/london-plan/current-londonplan/

Hoare Lea (2014) - The Goodsyard, Bishopsgate - Masterplan Energy Strategy -TG14

IEA (2014), "World energy balances", IEA World Energy Statistics and Balances (database), DOI: http://dx.doi.org/10.1787/data-00512-en (accessed on 20 Feb 2017)

IEA, 2010. Energy Technology Perspectives 2010: Strategies and Scenarios to 2050, OECD/IEA, Paris

Jabareen Y. 2006. Sustainable urban forms: Their typologies, models, and concepts. Journal of Planning Education and Research, 26, pp. 38-52

Knowles RL, 1981. Sun Rhythm Form, MIT Press, Cambridge, MA, 1981.

Knowles, R.L., 2003. The solar envelope: its meaning for energy and buildings. Energy and buildings, 35(1), pp.15-25. 
Kolokotroni, M., Ren, X., Davies, M. and Mavrogianni, A., 2012. London's urban heat island: Impact on current and future energy consumption in office buildings. Energy and buildings, 47, pp.302311.

Liu X, Sweeney J, 2012. Modelling the impact of urban form on household energy demand and related CO2 emissions in the Greater Dublin Region, Energy Policy, 46, pp 359-369

Marrs C. 2016. High demand for high-rise: Where will the City put its new skyscrapers? Architects Journal http://www.architectsjournal.co.uk/news/high-demand-for-high-rise-where-will-thecity-put-its-new-skyscrapers/8691245.fullarticle

Martilli A. 2014. An idealized study of city structure, urban climate, energy consumption, and air quality, Urban Climate, 10, pp 430-446

Martins TAL, Adolphe L, Bastos LEG, 2014. From solar constraints to urban design opportunities: Optimization of built form typologies in a Brazilian tropical city, Energy and Buildings, 76, pp. 4356

Mourshed M. 2016. Climatic parameters for building energy applications: A temporal-geospatial assessment of temperature indicators, Renewable Energy, 94, pp 55-71

New London Architecture Annual Update March 2016 London Tall Buildings Survey http://www.newlondonarchitecture.org/docs/1 nla ir tall buildings single-1.pdf

Newman, P.W. and Kenworthy, J.R., 1989. Gasoline consumption and cities. Journal of the American Planning Association, 55(1), pp.24-37.

$\mathrm{Ng}$, E., 2009. Policies and technical guidelines for urban planning of high-density cities-air ventilation assessment (AVA) of Hong Kong. Building and environment, 44(7), pp.1478-1488.

OECD (2012), Compact City Policies: A Comparative Assessment, OECD Publishing, Paris. DOI: http://dx.doi.org/10.1787/9789264167865-en

Oikonomou E, Davies M, Mavrogianni A, Biddulph P, Wilkinson P, Kolokotroni M. 2012. Modelling the relative importance of the urban heat island and the thermal quality of dwellings for overheating in London, Building and Environment, 57, pp 223-238

Oke TR, 1987. Boundary Layer Climate, London: Methuen

Olgyay V. 1963. Design With Climate: Bioclimatic Approach to Architectural Regionalism, Princeton University Press

Porse E, Derenski J, Gustafson H, Elizabeth Z, Pincetl S. 2016. Structural, geographic, and social factors in urban building energy use: Analysis of aggregated account-level consumption data in a megacity, Energy Policy, 96, pp 179-192

Ratti C, Baker N, Streemers K. 2005. Energy consumption and urban texture, Energy and Buildings, 37, pp 762-776

Ratti C, Raydan D, Steemers K. 2003. Building form and environmental performance: archetypes, analysis and an arid climate, Energy and Buildings, 35, pp. 49-59

Rodríguez MC, Dupont-Courtade L, Oueslati W. 2016. Air pollution and urban structure linkages: Evidence from European cities, Renewable and Sustainable Energy Reviews, 53, pp 1-9

Rodríguez-Álvarez J, 2016. Urban Energy Index for Buildings (UEIB): A new method to evaluate the effect of urban form on buildings' energy demand, Landscape and Urban Planning, 148, pp 170187

Schwarz N, 2010. Urban form revisited - Selecting indicators for characterising European cities, Landscape and Urban Planning, 96, pp 29-47 
Steadman P, Hamilton I, Evans S. 2014. Energy and urban built form: an empirical and statistical approach, Building Research \& Information, 42, pp. 17-31

Steemers K, Raydan D, Ratti C, Robinson CD, 2000. PRECis: Assessing the Potential for Renewable Energy in Cities. Final Report, Cambridge.

Stone Jr. B, Rodgers MO. 2001. Urban Form and Thermal Efficiency: How the Design of Cities Influences the Urban Heat Island Effect, Journal of the American Planning Association, 67, pp. 186-198.

Sunderland, K.M., Mills, G. and Conlon, M.F., 2013. Estimating the wind resource in an urban area: A case study of micro-wind generation potential in Dublin, Ireland. Journal of Wind Engineering and Industrial Aerodynamics, 118, pp.44-53.

Tavernor R, Gassner G. 2010. Visual consequences of the plan: Managing London's changing skyline, City, Culture and Society, 1, pp. 99-108

U.S. Dept of Energy (US DOE), n.d. Commercial Reference Buildings, Office of Energy Efficiency and Renewable Energy, US DoE, available at: https://energy.gov/eere/buildings/commercialreference-buildings (last accessed 13.03.2017)

Williams K, Burton E, Jenks M. 2000. Achieving Sustainable Urban Form. London: E \& FN Spon

Wolf T, McGregor G. 2013. The development of a heat wave vulnerability index for London, United Kingdom, Weather and Climate Extremes, 1, pp 59-68

Yannas S. 1994. Solar Energy and Housing Design: Principles, Objectives, Guidelines (Vol. 1) AA Publishing

Yao R, Steemers K, 2005. A method of formulating energy load profile for domestic buildings in the UK, Energy and Buildings, 37(6), pp 663-671

Yin Y, Mizokami S, Maruyama T, 2013. An analysis of the influence of urban form on energy consumption by individual consumption behaviours from a microeconomic viewpoint, Energy Policy, 61, pp 909-919 

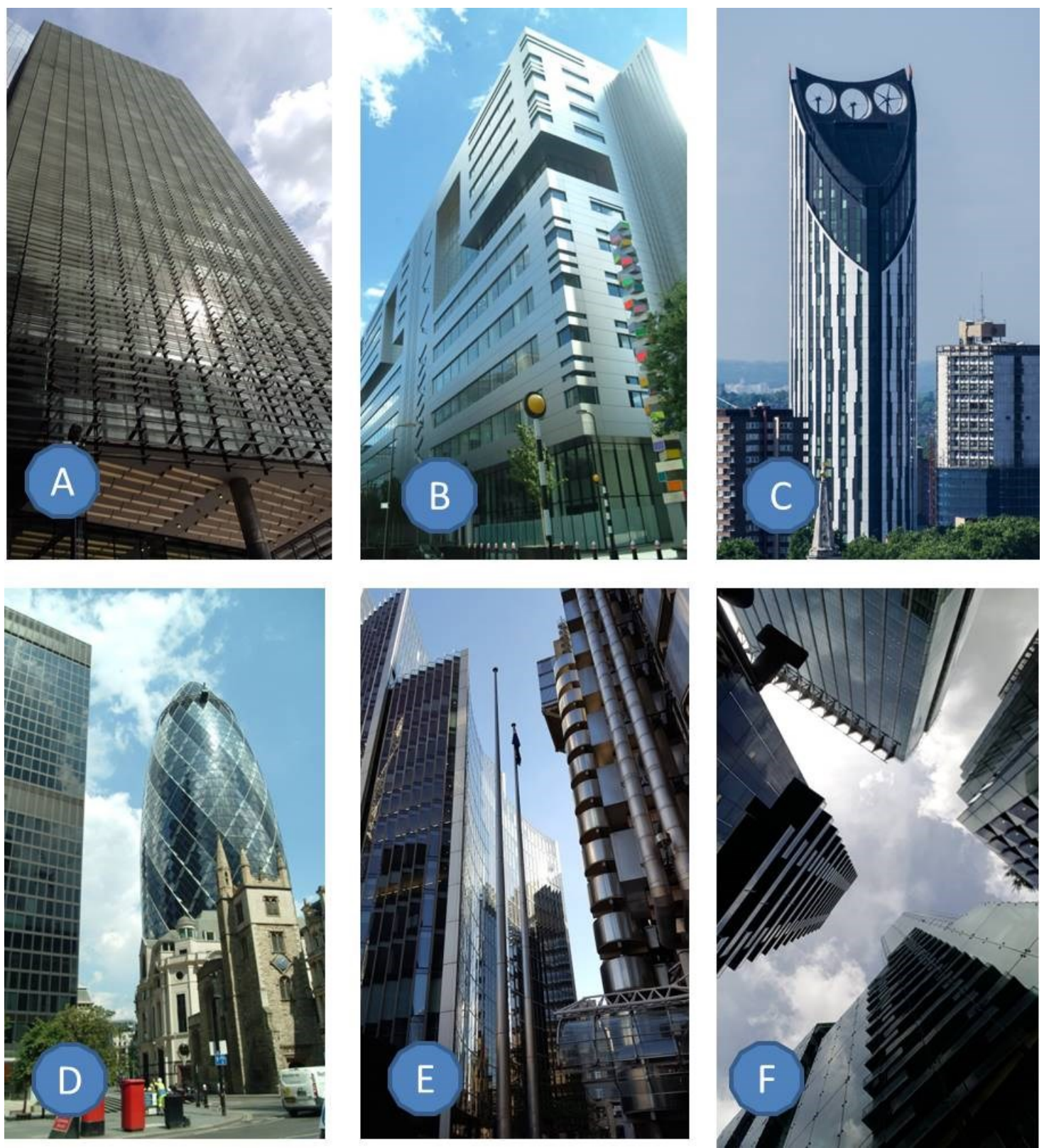

Figure $1-A) 25$ Ropemaker Street -full length brise-soleil to offset passive gains to south facing glazed facade; B) 5 Broadgate, highly polished surface reflects energy back into surrounding setting ; C) The Strata Tower (CUser: Colin / Wikimedia Commons / CC BY-SA 4.0) residential; renewable energy technology reliant on unobstructed access to resource currently not protected; D) 30 St Marys Axe -modern building form inserted into low lying setting; E) Proximity of 1 Lime Street (Lloyd's building) to 51 Lime Street (The Willis building) intercepts afternoon solar glare and creates wind funnelling effects ; F) Ropemaker Place dense cluster of tall buildings limit levels of solar receipt at ground level! 


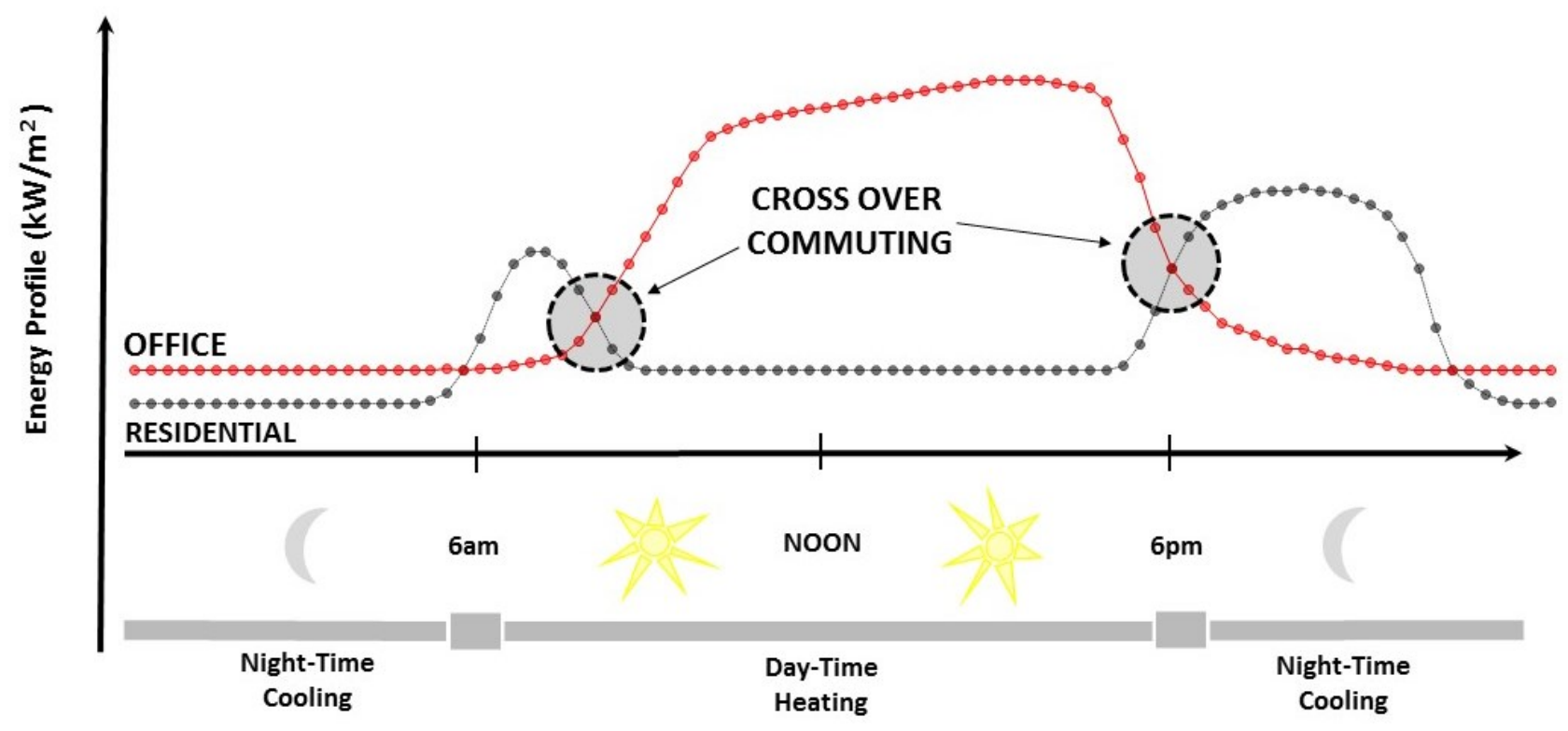

Figure 2: A schematic view of the likely daily energy demand profiles for typical 'Residential' and 'Commercial' buildings 


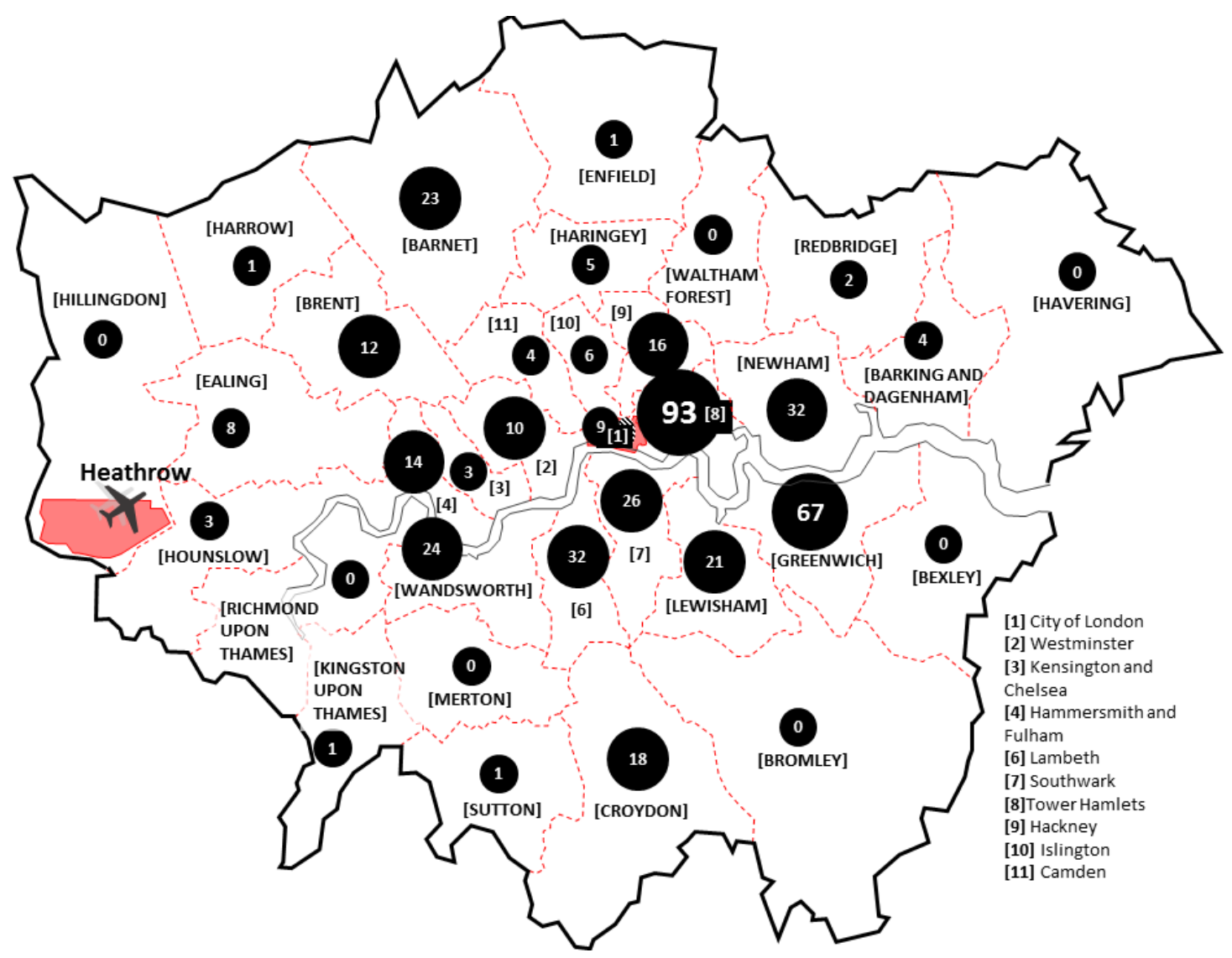

Figure 3 Location and number (by borough) of the 436 proposed towers (>20 storeys) Greater London -- after New Architecture London. 


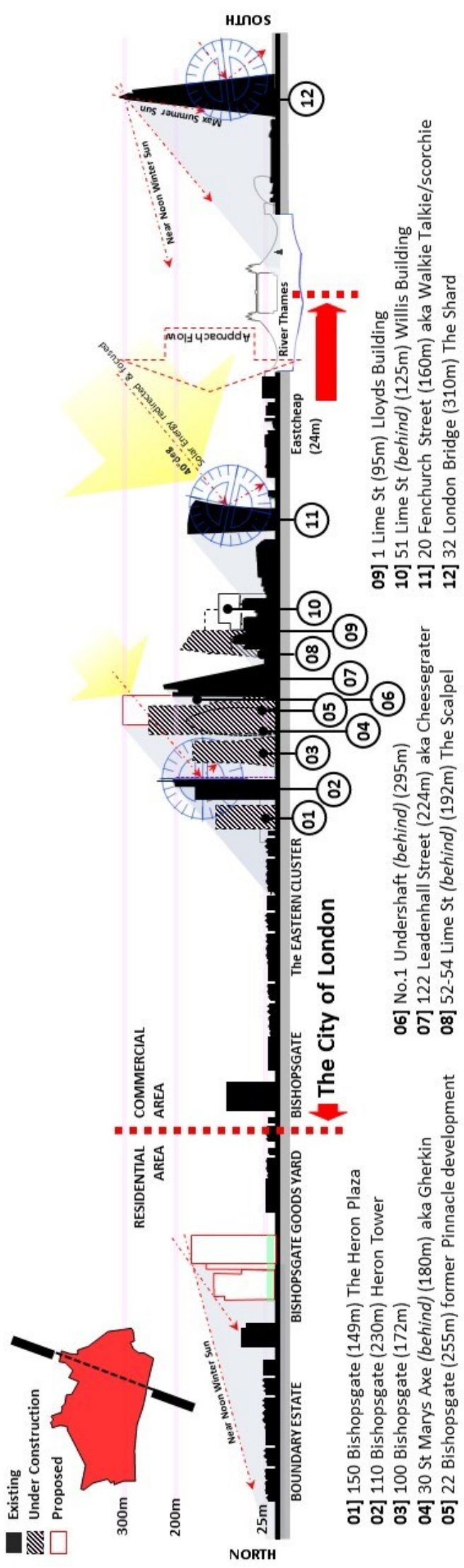

Figure 4: City profile Section showing the Eastern Cluster - City of London 

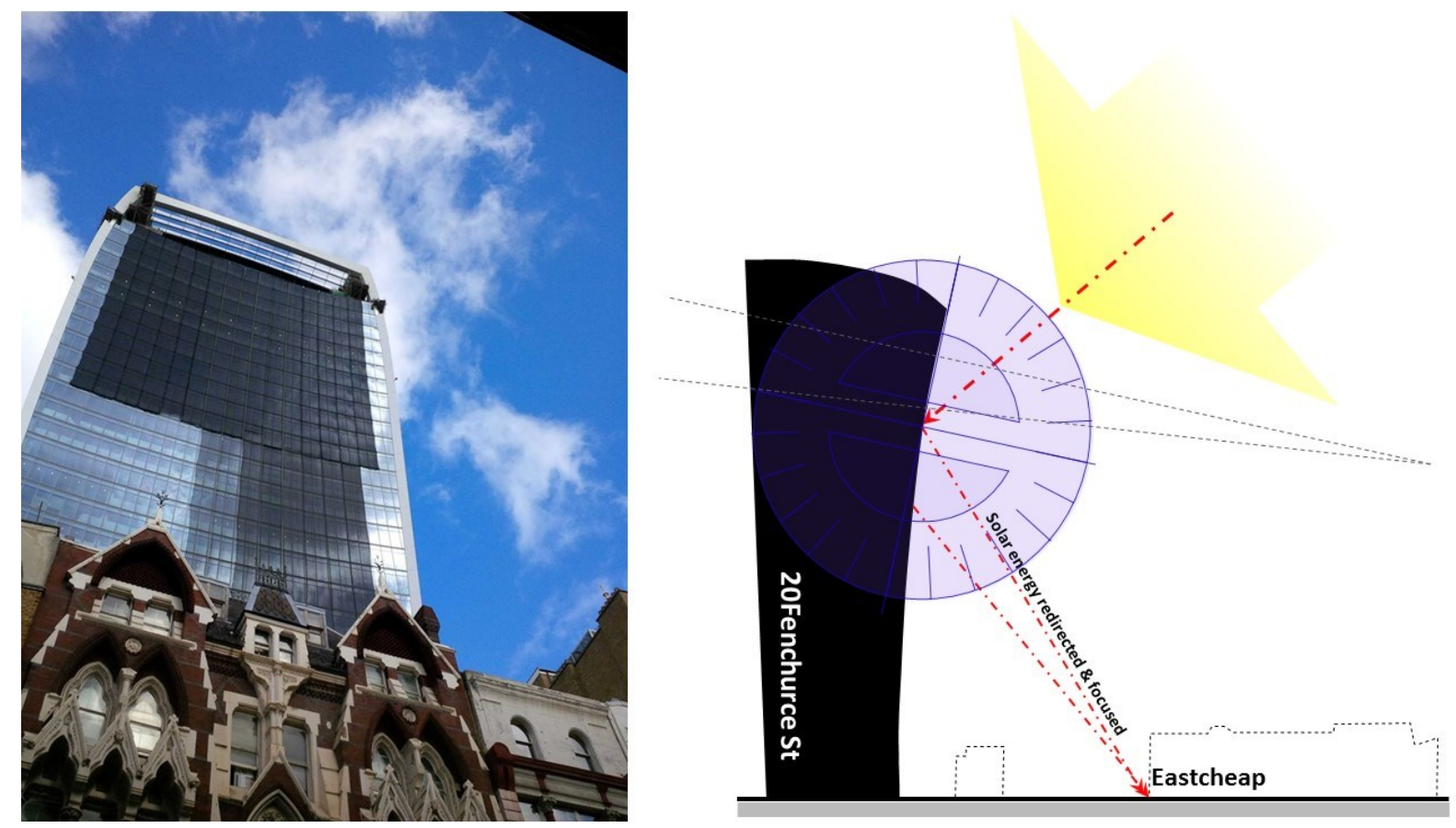

Figure 5. 20 Fenchurch Street -a) looking towards the South Façade from Eastcheap showing temporary covering and b) schematic showing angle and focus of solar beam for early September

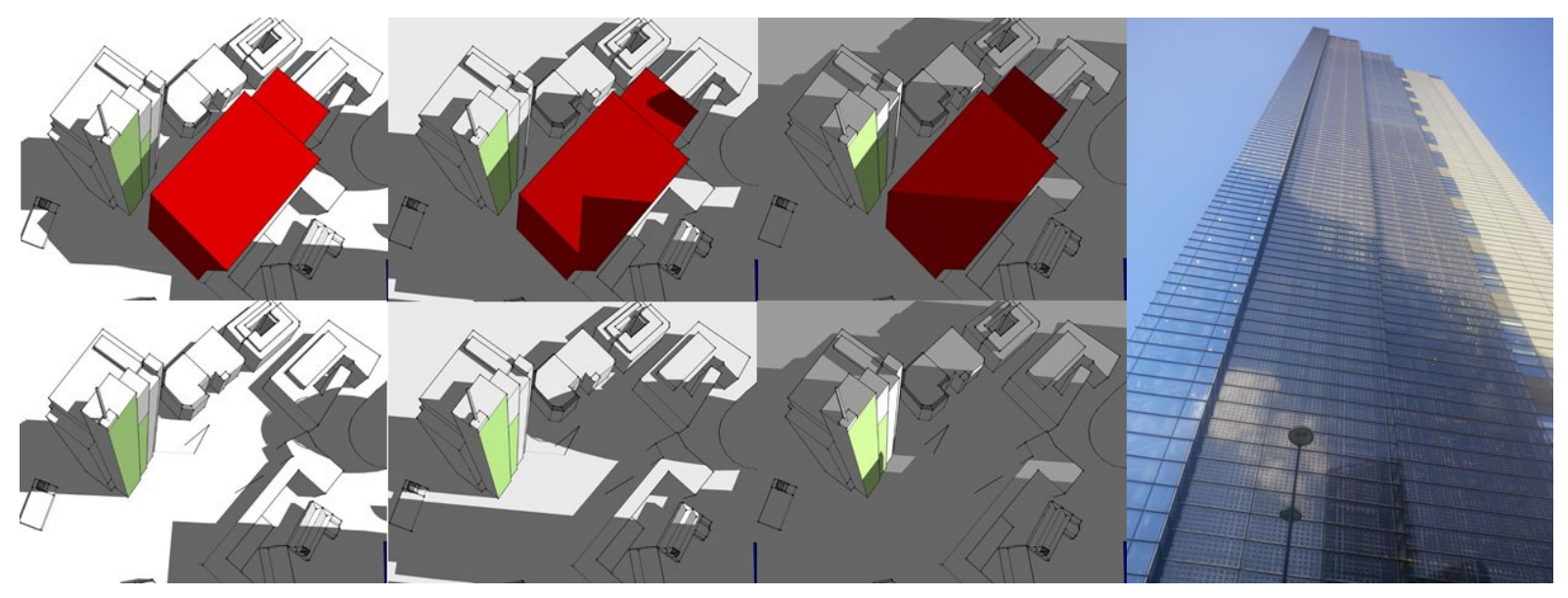

Figure 6. a) the Heron Tower 110 Bishopsgate with (top) \& without (bottom) 100 Bishopsgate b) the Heron Tower 200m high PV array 


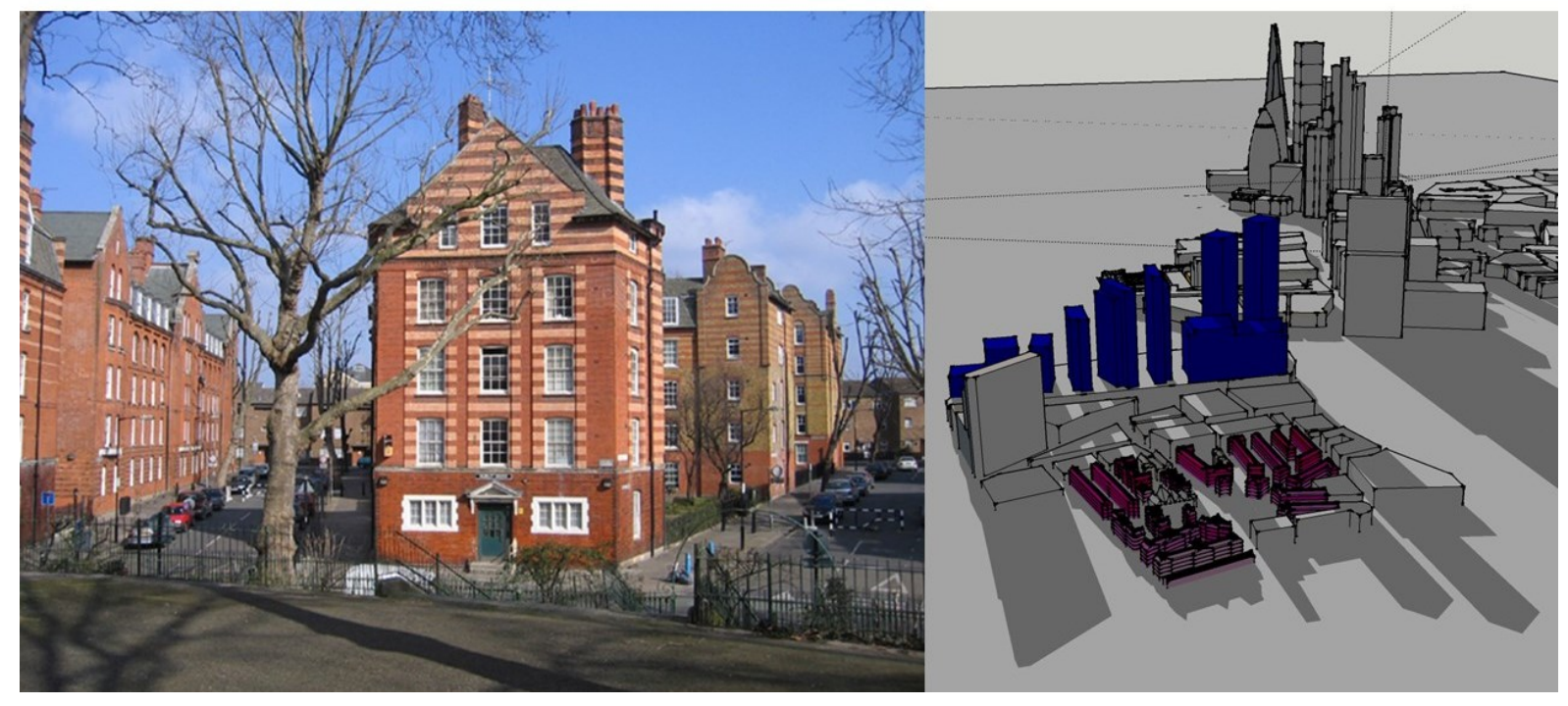

Figure 7. a) The Boundary Estate showing current levels of solar access into streets b) Bishops Goods Yard showing and 3D model of the proposed, but now in abeyance, Bishopsgate Goods Yard Development overshadowing the underlying Boundary Estate - both images are for February early afternoon. 
Appendix 1

Modelling of tall commercial Buildings - 110BG case study

The shadowing impact of the tall building development to the south of 110BG was assessed in two steps. First, annual illuminances are calculated for the south-facing façade of 110BG with and without the obstructing building using RADIANCE, a well-established tool for such analysis. The impact on the integrated PV array was computed in EnergyPlus simulation tool by using a simple model of photovoltaics and applying a moderate constant efficiency of $14 \%$. Electricity generation of an obstructed PV array dropped by $40 \%$ when compared to a same PV array in unobstructed settings. Second, an analysis of the thermal performance of an indoor zone (11-meter deep) behind the south-facing façade was performed using EnergyPlus. Currently, this space is unoccupied but if it were used as office space, the shading provided by the neighbouring building would have two impacts: the annual cooling demand would be lowered by $30 \%$ while annual heating requirements would increase by $35 \%$ (to $4 \%$ of the total load). However, the impact of shading on heating is of less importance due to the daytime occupancy of offices that drives cooling need. These calculations were based on these assumptions:

- PV array was replaced with a $75 \%$ glazed curtain wall. Wall U-value was set to $0.24 \mathrm{~W} / \mathrm{m}^{2} \mathrm{~K}$ while windows were assumed to have U-value of $0.9 \mathrm{~W} / \mathrm{m}^{2} \mathrm{~K}$. Other important characteristics of glazing included in a model were solar heat gain coefficient and visible transmittance which values were set to 0.5 and 0.65 respectively.

- Office space was occupied between 7:30am and 7:30pm with a heating setpoint set to $19^{\circ} \mathrm{C}$ and a cooling setpoint set to $22^{\circ} \mathrm{C}$.

- Internal heat gains from lighting and equipment were limited to occupied hours only and were assumed to be $12 \mathrm{~W} / \mathrm{m}^{2}$ and $15 \mathrm{~W} / \mathrm{m}^{2}$ respectively. An occupants' density of 10 $\mathrm{m}^{2} /$ person was applied during occupied hours.

- Ventilation and infiltration gains/losses were also included in an analysis. It was assumed that $10 \mathrm{l} / \mathrm{s}$ per person was supplied when occupants are present, while infiltration was fixed to 0.3 air changes per hour all the time.

\section{Appendix 2}

Modelling of tall residential Buildings - Bishopsgate Goodsyard (BGY)

The impact of the proposed development Bishopsgate Goodsyard (BGY) on the Boundary Estate $(B E)$, was examined using EnergyPlus to simulate: the current energy demands of BE with and without BGY and the expected energy demands of $B E$ after refurbishment, with and without BGY. Detailed models of over 20 buildings in $\mathrm{BE}$ were created and the following assumptions were made:

- Approximately $60 \%$ of the total floor area was assumed to be bedroom zones, while the rest was defined as living areas. Half of the living areas were constantly occupied, while the rest was following the pattern of the working family.

- Bedroom zones were occupied between 10pm and 8am. Living areas in the working family occupied properties had occupied time between $5 \mathrm{pm}$ and $10 \mathrm{pm}$ for Weekdays and between $8 \mathrm{am}$ and $10 \mathrm{pm}$ for Weekends. Constantly occupied living areas had occupied time from 8am to $10 \mathrm{pm}$ regardless the day of the week.

- It was assumed that the heating is available during occupied time in order to meet heating setpoints of $19^{\circ} \mathrm{C}$ and $21^{\circ} \mathrm{C}$ in bedrooms and living areas respectively. Occupancy density of 8 $\mathrm{m}^{2}$ per person and lighting/equipment gains of $9 \mathrm{~W} / \mathrm{m}^{2}$ were assigned to bedroom zones. Slightly higher figures were assigned to living areas $\left(10 \mathrm{~m}^{2}\right.$ per person for occupancy density and $11.5 \mathrm{~W} / \mathrm{m}^{2}$ for internal gains). 
To represent the existing building fabric: walls are comprised of uninsulated brick with no cavity (Uvalue of $1.6 \mathrm{~W} / \mathrm{m}^{2} \mathrm{~K}$ ); U-values of ground floor and roof, also uninsulated, were set to $2.8 \mathrm{~W} / \mathrm{m}^{2} \mathrm{~K}$ and $1.4 \mathrm{~W} / \mathrm{m}^{2} \mathrm{~K}$ respectively; low quality single glass pane windows, which covers approximately $30 \%$ of exposed walls, had U-value of $5.9 \mathrm{~W} / \mathrm{m}^{2} \mathrm{~K}$, solar heat gain coefficient of 0.85 and visible transmittance of 0.9 and; finally, poor air tightness of existing buildings is represented with an infiltration rate of 0.5 air changes per hour.

Post refurbishment measures included: replacing windows with double Low-E glazing with U-value of $2 \mathrm{~W} / \mathrm{m}^{2} \mathrm{~K}$, solar heat gain coefficient of 0.6 and visible transmittance of 0.75 ; insulating all exposed construction elements to improve the U-values of external walls, roofs and floors to $0.28 \mathrm{~W} / \mathrm{m}^{2} \mathrm{~K}$, $0.18 \mathrm{~W} / \mathrm{m}^{2} \mathrm{~K}$ and $0.28 \mathrm{~W} / \mathrm{m}^{2} \mathrm{~K}$, respectively and; improved sealing to reduce infiltration to 0.25 air changes per hour. 